\title{
EFFECTS OF SOME INSECTICIDES APPLIED IN SUBLETHAL CONCENTRATIONS ON THE SURVIVAL AND LONGEVITY OF Aphidius ervi (Haliday) (HYMENOPTERA: APHIDIIDAE) ADULTS
}

\author{
Jaime E. Araya ${ }^{1 *}$, Manuel Araya $^{1}$, and María Angélica Guerrero ${ }^{1}$
}

\begin{abstract}
The effects of four insecticides (dimethoate, pirimicarb, imidacloprid, and spinosad) applied in an ST4 Potter tower at sublethal concentrations (50\% of those recommended commercially for aphid control) were studied in the laboratory on the aphidiid Aphidius ervi (Haliday) adults, an important parasitoid of the pea aphid Acyrthosiphon pisum (Harris). The most selective treatment on the hymenopteran was imidacloprid, followed in decreasing order by spinosad, pirimicarb, and finally dimethoate, which quickly eliminated the parasitoid and thus its capacity to produce progeny. Three toxicity groups were distinguished in the study. The least damaging treatment to adults of A. ervi was imidacloprid, followed by a group of medium toxicity made up of spinosad and pirimicarb, and lastly dimethoate, which was extremely toxic to A. pisum.
\end{abstract}

Key words: Acyrthosiphon pisum, Aphidius ervi, dimethoate, green pea aphid, imidacloprid, pirimicarb, spinosad.

\section{INTRODUCTION}

After years of trust in pesticides, natural enemies are recognized as essential pest control agents in the long run (Banken and Stark, 1998). These organisms are important in the dynamics of communities of arthropods. Natural control agents interact with their hosts in a cyclical homeostasis between their populations (Rodríguez, 1980). Parasitoids are different from predators in that the first spend most of their life inside their hosts, and thus are subjected to the same factors of mortality (Ives and Settle, 1996). Hymenopteran parasitoids are important in natural control of aphids, particularly pea and cereal aphids, and are used in biological control programs of them in diverse crops (Pungerl, 1984).

Although biological control is desirable, some pests having high reproductive rate and mobility as certain aphids, are very difficult to control only biologically, and require selective insecticides acting together with natural control (Stark and Rangus, 1994). Integrated pest management includes natural enemies, complemented with selective insecticides when necessary (Metcalf, 1982).

${ }^{1}$ Universidad de Chile, Facultad de Ciencias Agronómicas, Casilla 1004, Santiago, Chile.*Corresponding author (jearaya@uchile.cl). Received: 02 April 2009.

Accepted: 10 September 2009.
In Chile, the pea aphid Acyrthosiphon pisum (Harris) (Hemiptera: Aphididae) is a primary pest on diverse legume crops (Prado, 1991), which is controlled often with systemic insecticides. The leaves of the host plants become twisted and deformed, flower shoots do not grow and buds become atrophied. Plants infested get yellowish, and sometimes die. Soft winters and moderate temperature favour heavy infestations. This aphid is also a vector of viral diseases, such as Bean mosaic virus (Artigas, 1994).

Some insecticides used against aphids are pirimicarb (carbamate: 2-dimethylamino-5,6-dimethylpyrimidin-4yl dimethylcarbamate), dimethoate, (organophosphate: $O, O$-dimethy $1 \mathrm{~S}-$ methylcarbamoy $1 \mathrm{meth}$ y 1 phosphorodithioate) and imidacloprid (neonicotinoid: (E)-1-(6-chloro-3-pyridylmethyl)- $N$-nitroimidazolidin-2ylideneamine). Dimethoate is toxic to many insect pests and bees; pirimicarb poses a risk to these pollinators, and is a specific aphicide, not toxic to natural enemies of aphids. Imidacloprid is effective mainly against sap-sucking insects, and possesses low toxicity to natural enemies and a large residual period (Barberá, 1989). Spinosad, a mixture of spinosyns A and D, which confer it high toxicity against numerous insects, comes from fermentation of a soil bacterium, Saccharopolyspora spinosa Mertz \& Yao. Differently to other physiologically comparable products, it acts onto a different site of neuromuscular action, which translates into a hyperexcitation which paralyzes the insect from neuronal fatigue (Thompson et al., 1999). 
Although spinosad is not recommended as an aphicide (in Chile or elsewhere), it is used on crops against many pests. Many of these ecosystem harbour aphids, which justifies the study of its effects on both pests and their parasitoids. Today, more than studying the toxic effect of pesticides on pests, there is a trend to evaluate their innocuousness towards natural enemies (Banken and Stark, 1998).

Aphidius ervi (Haliday) (Hymenoptera: Aphidiidae) is a common parasitoid of A. pisum and other aphids (Cameron et al., 1984; Prado, 1991; Bueno et al., 1993; Sequeira and Mackauer, 1993; Christiansen-Weniger and Hardie, 1997). In Australia, A. ervi regulates density of Acyrthosiphon spp. on alfalfa (Medicago sativa L.) and other legume crops; parasitism increased from 1 through 90\% the second year from its introduction (Milne and Bishop, 1987). In previous studies, Zuazúa et al. (2000) observed that the average of $A$. ervi adults treated with commercial dosages of the same insecticides included in this study did not vary significantly from that in the untreated control, and related the effect of sublethal concentrations on A. pisum with the preservation of $A$. ervi in the agroecosystem.

Although many insecticides exert good aphid control in the short run, the application of broad spectrum products has ended often with their natural enemies, and caused a surge of pests under that control (Bartlett, 1958; Kain et al., 1976; Croft, 1989).

In general, adult hymenopteran parasitoids are at least as susceptible to contact with insecticides as their respective hosts. Thus, many adult parasitoids are destroyed during programs of control with non selective insecticides (Bartlett, 1958). Integrated pest management includes the action of natural enemies to reduce the density of the first to levels near the economic threshold, which allows relatively low population densities of pests, and with it, the continued action of their natural enemies. In the study of an insecticide, keeping in mind the preservation of these control agents, all sublethal effects have to be considered. Together with establishing the longevity of a parasitoid after application of an insecticide, it is necessary to evaluate how this will affect its progeny and descendants.

The objective of this research was to determine in the laboratory the possible sublethal effects of the insecticides dimethoate, pirimicarb, imidacloprid, and spinosad onto adults of A. ervi.

\section{MATERIALS AND METHODS}

This study was done in two stages, in the Laboratory of Toxicology, Facultad de Ciencias Pecuarias, Universidad de Chile, Santiago, Chile.
Rearing. The aphids and the parasitoid were collected from alfalfa in Santiago. Identification of both species was confirmed using keys (Stary, 1966; Mertins, 1985; Pike et al., 1997). The parasitoid was verified also by comparison with specimens from colonies at the Laboratory of Chemical Ecology, College of Sciences, University of Chile, Santiago.

Colonies of A. pisum were established with neonate nymphs onto faba bean plants (Vicia faba L.) on $13 \mathrm{~cm}$ diameter pots containing plant litter, sand, and humus (1:1:1), covered with transparent PVC cylinders with the top covered with fine cloth, which were maintained at $20{ }^{\circ} \mathrm{C}$. These cylinders were used both to rear the aphids and A. pisum on them, and allowed to obtain the parasitoid continuously starting with the specimens obtained on the alfalfa; the adult parasitoids were fed with $10 \%$ honey on cotton wicks (Bueno et al., 1993). When the plants became deteriorate and the aphids tended to migrate, or their populations risked being maintained, new potted plants were added. Parasitism developed so continuously, allowing enough and safe material.

Application of insecticides. The concentrations applied corresponded to half the average of the range recommended commercially for each product (Table 1). Volumes applied onto standard glass Petri dishes were equivalent to $1000 \mathrm{~L} \mathrm{ha}^{-1}$.

Treatments. Treatments to adults of A. ervi were applied with a Potter tower, spraying $0.5 \mathrm{~mL}$ of each insecticide (all products less than $1 \mathrm{yr}$-old) diluted in water (at 12 psi) onto $9 \mathrm{~cm}$ diameter glass Petri dishes $\left(63.2 \mathrm{~cm}^{2}\right)$ at the concentrations indicated in Table 1. Once the treated surface dried, 23 parasitoids younger than $24 \mathrm{~h}$ of age were placed per dish, obtained from the rearing cylinders, and were maintained at room temperature during $1 \mathrm{~h}$. To ensure no untreated areas in the dish, $0.5 \mathrm{~mL}$ of the corresponding preparation were sprayed on the internal

Table 1. Insecticides and concentrations applied onto adults of Aphidius ervi in Petri dishes.

\begin{tabular}{lcc}
\hline & \multicolumn{2}{c}{ Concentrations applied in 1000 L water } \\
\cline { 2 - 3 } Treatments & $\begin{array}{c}\text { Active } \\
\text { ingredients }\end{array}$ & $\begin{array}{c}\text { Commercial } \\
\text { products }\end{array}$ \\
\hline Dimethoate & $15000 \mathrm{~mL}$ & $37500 \mathrm{~mL}$ \\
Spinosad & $3000 \mathrm{~mL}$ & $6250 \mathrm{~mL}$ \\
Imidacloprid & $4375 \mathrm{~mL}$ & $12500 \mathrm{~mL}$ \\
Pirimicarb & $4375 \mathrm{~g}$ & $8800 \mathrm{~g}$ \\
Control & - & - \\
\hline
\end{tabular}


side of the Petri dish cover. The calculation of the amount of insecticide was done by surface.

A $5 \times 2 \mathrm{~cm}$ ventilation hole $\left(10 \mathrm{~cm}^{2}\right)$ covered with fine cotton cloth was made on the Petri dish covers to avoid a lethal chamber effect. Dead specimens after 1 $\mathrm{h}$ exposure were counted and sexed by presence of the oviscapt on females. The survivors were counted, taken to clean glass vials with food (10\% honey in water), and maintained at $20{ }^{\circ} \mathrm{C}$; the survival in each vial was registered daily, retiring and sexing the dead individuals until the last microhymenopteran was dead. Control Petri dishes were applied just water. All surviving individuals were eliminated.

A completely random design was used with five treatments and four replicates. The results of survivorship $(\%)$ and longevity (d) of the wasp after $1 \mathrm{~h}$ exposure with the insecticides on treated Petri dishes were subjected to ANOVA analyses (Statgraphic 5.0 for MS-DOS), after normalization using the $\arcsin \sqrt{ } \mathrm{y}$ transformation when needed. Significant differences $(P \leq 0.05)$ between treatments were separated by mean of Duncan (1955) multiple range tests

\section{RESULTS AND DISCUSSION}

In a previous experiment, topically applied (sprayed directly onto the insects) insecticide treatments on $A$. pisum at sublethal concentrations obtained the results of mortality presented in Table 2 . In another previous test, the same insecticides and dosages were applied with a hand sprayer onto faba bean plants. Once dried, leaflets treated were caged into ventilated Petri dishes together with 5 d-old $A$. pisum nymphs. Mortality results are presented in Table 2.

Sublethal dosages $(50 \%$ of the average of the commercial range) had aphicide action on A. pisum (Table 2 ). The topical application of dimethoate, pirimicarb or imidacloprid caused $100 \%$ cumulative mortality at 48 h. The dry residues of spinosad caused only $57.5 \%$ mortality in that $48 \mathrm{~h}$ period, which reveals nonetheless its potential in integrated control of pests, as this lesser toxicity represents surviving hosts for $A$. ervi and avoids the disappearance of the parasitoid from an ecosystem exposed to more toxic insecticides.

Longevity of adults of $\boldsymbol{A}$. ervi. In this study, the average life-span of the adult parasitoids in the untreated control was $9.64 \pm 0.07 \mathrm{~d}$ (males: $9.95 \pm 0.19$; females: $8.55 \pm 0.38$ ), while in Ives and Settle (1996), they did not survive more than $5 \mathrm{~d}$. This variation could be due to differences in feeding and handling of the parasitoids between both studies.

A proportion of 0.26 females per male was obtained when rearing the parasitoid, previously to the experiment, near to the 0.36 in Zuazúa et al. (2000), but different from the two observed by Sequeira and Mackauer (1993). Anyhow, to obtain an adequate number of females is fundamental to maintain the colony, thus pairing must be maximized, exposing the females to males during 2-4 d, to ensure mating and sufficient progeny (ChristiansenWeniger and Hardie, 1997).

Table 2. Effect of topical application and of dry residues of insecticides at sublethal concentrations $(50 \%$ of commercial dosage) on mortality of Acyrthosiphum pisum.

\begin{tabular}{lccccc}
\hline & & \multicolumn{4}{c}{ Cumulative mortality (\%) after application } \\
\cline { 3 - 6 } Treatments & Concentrations $^{1}$ & $\mathbf{1 ~ h}$ & $\mathbf{2 4} \mathbf{~ h}$ & $\mathbf{4 8 ~ h}$ & $\mathbf{7 2 ~ \mathbf { ~ }}$ \\
\hline & \multicolumn{1}{c}{ Topical application onto aphids } \\
\hline Dimethoate & $37.50 \mathrm{~mL}$ & $50.00 \mathrm{~b}$ & $100.00 \mathrm{c}$ & - & - \\
Spinosad & $6.25 \mathrm{~mL}$ & $52.17 \mathrm{~b}$ & $73.91 \mathrm{~b}$ & $95.65 \mathrm{~b}$ & 100.00 \\
Imidacloprid & $12.50 \mathrm{~mL}$ & $75.00 \mathrm{c}$ & $100.00 \mathrm{c}$ & - & - \\
Pirimicarb & $8.80 \mathrm{~g}$ & $72.28 \mathrm{c}$ & $100.00 \mathrm{c}$ & - & - \\
Control & - & $0.00 \mathrm{a}$ & $0.00 \mathrm{a}$ & $0.00 \mathrm{a}$ & - \\
\hline
\end{tabular}

Aphids confined onto dry residues on faba bean leaves

\begin{tabular}{lccccc}
\hline Dimethoate & $37.50 \mathrm{~mL}$ & - & $100.00 \mathrm{~b}$ & - & - \\
Spinosad & $6.25 \mathrm{~mL}$ & - & $33.75 \mathrm{ab}$ & $57.50 \mathrm{~b}$ & $87.50 \mathrm{~b}$ \\
Imidacloprid & $12.50 \mathrm{~mL}$ & - & $83.75 \mathrm{c}$ & $100.00 \mathrm{c}$ & - \\
Pirimicarb & $8.80 \mathrm{~g}$ & - & $100.00 \mathrm{c}$ & - & - \\
Control & - & - & $0.00 \mathrm{a}$ & $0.00 \mathrm{a}$ & $0.00 \mathrm{a}$ \\
\hline
\end{tabular}

${ }^{1}$ In both studies, $\mathrm{n}=23$ individuals per treatment, with four replicates. Concentrations to apply of commercial products per $1000 \mathrm{~L}$ correspond to $50 \%$ the average of the range recommended commercially for each product, with an application volume of $1000 \mathrm{~L} \mathrm{ha}^{-1}$.

Means in a column with different letters are significantly different according to Duncan multiple range tests $(\mathrm{P} \leq 0.05)$. 
Survival of adults of $\boldsymbol{A}$. ervi. After $24 \mathrm{~h}$ exposure to the dry insecticide residues, insecticides caused the death of all parasitoids ( $1 \mathrm{~h}$ for dimethoate) (Table 3 ). In the study of Lankin et al. (1997), metamidophos (another phosphorous insecticide) affected also severely the survival of adults of Diaeretiella rapae (McIntosh) exposed to residues. In the studies of Roos and Melo (1976), dimethoate was very toxic to all stages of development of the coccinellids Cycloneda sanguinea (L.) and Eriopis connexa (Germar). These results agree with Bartlett (1963), who considered dimethoate as a medium to high toxicity product. Imidacloprid had an intermediate range, with an average survival similar to the control. Spinosad and pirimicarb were not different from the control.

\section{Longevity of adults of $A$. ervi after $1 \mathrm{~h}$ exposure to} contact with the insecticides. In general longevity, there were significant differences between treatments according to the toxicity of the insecticides evaluated (Table 3). Dimethoate was the most toxic insecticide, which at the end of the first day caused total mortality and did not allow to measure longevity of males or females. Next was pirimicarb followed by spinosad. Both of these treatments presented lesser toxicity than dimethoate, but at the same time greater $(\mathrm{P} \leq 0.05)$ than the control. Among the insecticides evaluated, imidacloprid caused the least effect on life-span of adults (males, females, and the average of both). The general means of longevity of males and females in the trials were not significantly different. Neither were differences when comparing the longevity of both sexes in all treatments through a t-Student test, Lankin et al. (1997) did not find also differences in susceptibility between adults of $D$. rapae of both sexes exposed to contact with fenvalerate and metamidophos. However, Sequeira and Mackauer (1993) observed lower mortality on males than females of A. smithi Shao-Rao on foliage treated with carbaryl; the active searching behaviour of females increased their exposure to the insecticide.
In this study there were differences between pirimicarb and imidacloprid, differing from the results of Zuazúa et al. (2003), who did not find differences between both compounds in a laboratory comparison which included also other insecticides (thiacloprid and azadirachtin). Differences in results may be due to different laboratory conditions.

Stark et al. (1995) found that diazinon (an organophosphate insecticide, comparable by its mode of action only to dimethoate) was more toxic in terms of survival of $A$. ervi adults than to its host A. pisum, while imidacloprid was more selective in favour of the parasitoid.

In the laboratory pirimicarb has shown a lesser toxicity than imidacloprid to adults of Aphelinus mali (Haldeman) (Hymenoptera: Aphelinidae) (Cohen et al., 1996). However, the high toxicity of imidacloprid observed in the field would be lower due to the possibility of applying it to the roots, thus reducing direct contact with the parasitoids.

Besides being unnecessary, wide action spectrum insecticides as dimethoate make collapse populations of beneficial insects; however, pirimicarb at $1 / 4$ the concentration recommended produces efficient control of aphids on cereals, and does not have considerable toxic effects on beneficial fauna (Cornale et al., 1996).

In studies of toxicity of diverse insecticides, Roos and Melo (1976) observed a great selectivity of pirimicarb on diverse stages of development of two coccinellid beetles, while dimethoate was very toxic. Bartlett (1963) classified this insecticide as a medium to high toxicity product, and pirimicarb as a compound clearly selective to the same coccinellids. As generalist predators, coccinellids have a larger pool of detoxifying enzymes and cannot be compared with parasitoids, which are more specific and have a less diverse enzymatic pool. However, Summers et al. (1975) verified the innocuousness of pirimicarb to adults and larvae of coccinellids, Chrysopa sp. (Neuroptera), Nabis sp., Orius sp. (both Hemiptera), and also the aphidiid hymenopteran A. smithi.

Table 3. Adults of Aphidius ervi surviving after $24 \mathrm{~h}$ exposure to insecticides at sublethal concentrations onto a treated surface and longevity ( \pm standard error) by sex and general average.

Longevity $(d) \pm$ standard error

\begin{tabular}{lcccc}
\cline { 2 - 5 } Treatments & Surviving adults & Males & Females & Average \\
\hline Dimethoate & $0.00 \pm 0.00 \mathrm{a}$ & $0.00 \pm 0.00 \mathrm{a}$ & $0.00 \pm 0.00 \mathrm{a}$ & $0.00 \pm 0.00 \mathrm{a}$ \\
Spinosad & $23.00 \pm 0.00 \mathrm{c}$ & $6.89 \pm 0.15 \mathrm{~b}$ & $6.40 \pm 0.29 \mathrm{c}$ & $6.78 \pm 0.05 \mathrm{c}$ \\
Imidacloprid & $22.00 \pm 0.41 \mathrm{~b}$ & $8.70 \pm 0.30 \mathrm{c}$ & $8.10 \pm 0.24 \mathrm{~d}$ & $8.47 \pm 0.22 \mathrm{~d}$ \\
Pirimicarb & $22.75 \pm 0.25 \mathrm{c}$ & $6.64 \pm 0.19 \mathrm{~b}$ & $5.15 \pm 0.54 \mathrm{~b}$ & $6.31 \pm 0.16 \mathrm{~b}$ \\
Control & $23.00 \pm 0.00 \mathrm{c}$ & $9.95 \pm 0.19 \mathrm{~d}$ & $8.55 \pm 0.38 \mathrm{~d}$ & $9.64 \pm 0.07 \mathrm{e}$ \\
\hline
\end{tabular}

Means in a column with different letters are significantly different according to Duncan multiple range tests $(\mathrm{P} \leq 0.05)$. 
Based on laboratory studies, Patel et al. (1996) classified dimethoate as a highly toxic product $(>50 \%$ mortality) on D. rapae (McIntosh), an aphidiid parasitoid of the cabbage aphid Brevicoryne brassicae $\mathrm{L}$.

In the laboratory, under a $16: 8 \mathrm{~h}$ photoperiod, day and night temperatures of 20 and $10{ }^{\circ} \mathrm{C}$, respectively, Ives and Settle (1996) found that the period between egg laying of $A$. ervi and the formation of the mummy lasts $8.1 \pm$ $0.7 \mathrm{~d}$. The parasitoid emerges in $6.1 \pm 0.8 \mathrm{~d}$, with a total period between egg laying and emergence of $14.7 \pm 1 \mathrm{~d}$. The adults are short lived and normally do not survive over $5 \mathrm{~d}$.

When using insecticides, the relationship between the amount of toxicant and the unit of live weight is greater for smaller organisms, and often, the parasitoids are smaller than their hosts (Croft, 1989). Thus, many insecticides are more toxic to natural enemies than pests (Croft and Brown, 1975). Studies indicate that, besides their lethality, insecticides have sublethal effects on microhymenopterans (Liotta, 1978; Maniglia, 1978), and affect their longevity, fecundity, juvenile development, rate of parasitism, longevity, fertility, egg laying, reproduction, and locomotion, and also cause deformities (Theiling and Croft, 1987; Banken and Stark, 1998), and alter the searching capacity of hosts or refuges against predators (Hoy and Dahlsten, 1984).

The impact of the action of natural enemies on pests may increase with the use of selective insecticides more toxic to the aphids than to beneficial organisms (Syrett and Penman, 1980). The selectivity of a pesticide can be physiological, a product of differences in absorption, detoxification, and excretion (Stark et al., 1995). There also exists an ecological selectivity, when the toxic elements do not reach the beneficial agent, but they do get to the pest in toxic concentrations (Roos and Melo, 1976). This laboratory study must be validated with a field one studying the interactions between A. ervi and A. pisum with the weather, foliage, selective forms of application, behaviours of search and migration, etc. Another research will have to adjust dosages of insecticides, to obtain an adequate relationship between effectiveness of treatment vs. parasitoid fecundity.

\section{CONCLUSIONS}

In conclusion, using sublethal dosages, three insecticide categories of toxicity in terms of reduction of longevity were distinguished toward A. ervi in this study. The most selective treatment was imidacloprid, followed by a group of medium toxicity formed by spinosad and pirimicarb, and last by dimethoate, which was extremely toxic to $A$. pisum.

\section{RESUMEN}

Efecto de algunos insecticidas aplicados en concentraciones subletales en la supervivencia y longevidad de adultos de Aphidius ervi (Haliday) (Hymenoptera: Aphidiidae). Se evaluaron en laboratorio los efectos de cuatro insecticidas (dimetoato, pirimicarb, imidacloprid, y spinosad) aplicados en torre Potter ST4 en concentraciones subletales (50\% de las dosis comerciales recomendadas para el control de áfidos) sobre adultos del afídido Aphidius ervi Haliday, un importante parasitoide del pulgón de la arveja Acyrthosiphon pisum (Harris). El tratamiento más selectivo sobre el himenóptero fue imidacloprid, seguido en orden decreciente por spinosad, pirimicarb, y finalmente dimetoato, compuesto que eliminó rápidamente al parasitoide y su capacidad de producir descendencia. Se distinguieron tres grupos de toxicidad. El tratamiento menos dañino para los adultos de $A$. ervi fue imidacloprid; seguido por un grupo de selectividad media formado por spinosad y pirimicarb; y por último dimetoato, que fue extremadamente tóxico.

Palabras clave: Acyrthosiphon pisum, Aphidius ervi, dimetoato, imidacloprid, pirimicarb, pulgón verde de la arveja, spinosad.

\section{LITERATURE CITED}

Artigas, J.M. 1994. Entomología económica: Insectos de interés agrícola, forestal, médico y veterinarios (nativos, introducidos y susceptibles de ser introducidos). Volumen I. 1250 p. Ediciones Universidad de Concepción, Concepción, Chile.

Banken, J., and J. Stark. 1998. Multiple routes of pesticide exposure and the risk of pesticides to biological controls: A study of neem and the sevenspotted lady beetle (Coleoptera: Coccinellidae). J. Econ. Entomol. 91:1-6.

Barberá, C. 1989. Pesticidas agrícolas. $4^{\mathrm{a}}$ ed. 603 p. Omega, Barcelona, España.

Bartlett, B. 1958. Laboratory studies on selective aphicides favoring natural enemies of the spotted alfalfa aphid. J. Econ. Entomol. 51:374-378.

Bartlett, B. 1963. The contact toxicity of some pesticide residues to hymenopterous parasites and coccinellid predators. J. Econ. Entomol. 56:694-698.

Bueno, B., A. Gutierrez, and P. Ruggle. 1993. Parasitism by Aphidius ervi (Hym.: Aphidiidae): preference for pea aphid and blue alfalfa aphid (Hom.: Aphididae) and competition with A. smithi. Entomophaga 38:273284. 
Cameron, P., W. Powell, and H. Loxdale. 1984. Reservoirs for Aphidius ervi Haliday (Hymenoptera: Aphidiidae), a polyphagous parasitoid of cereal aphids (Hemiptera: Aphididae). Bull. Entomol. Res. 74:647-656.

Christiansen-Weniger, P., and J. Hardie. 1997. Development of the aphid parasitoid, Aphidius ervi, in asexual and sexual females of the pea aphid, Acyrthosiphon pisum, and the blackberry-cereal aphid, Sitobion fragariae. Entomophaga 42:165-172.

Cohen, H., A. Horowitz, D. Nestel, and D. Rosen. 1996. Susceptibility of the wooly apple parasitoid, Aphelinus mali (Hym.: Aphelinidae), to common pesticides used in apple orchards in Israel. Entomophaga 41:225-233.

Cornale, R., M. Pozzati, C. Cavazzuti, e G. Burgio. 1996. Trattamenti insetticidi al grano: influenza su afidi e loro antagonisti naturali. Informatore Agrario 52:35-39.

Croft, B.A. 1989. Arthropod biological control agents and pesticides. 723 p. Wiley, New York, USA.

Croft, B.A., and A.W. Brown. 1975. Responses of arthropod natural enemies to insecticides. Annual Rev. Entomol. 20:285-336.

Duncan, D.B. 1955. Multiple F and multiple range tests. Biometrics 11:1-41.

Hoy, J.B., and D.L. Dahlsten. 1984. Effects of malathion and Staley's Bait on the behavior and survival of parasitic hymenoptera. Environ. Entomol. 13:14831486.

Ives, A., and W. Settle. 1996. The failure of a parasitoid to persist with a super-abundant host: the importance of the numerical response. Oikos 75:269-278.

Kain, W., M. Esson, R. Holland, and D. Atkinson. 1976. Preliminary studies of chemical control of bluegreen lucerne aphid. 590 p. In Hartley, M.J. (ed.) Proc. $29^{\text {th }}$ New Zealand Weed Pest Control Conference, Christchurch. 3-5 August 1976. The New Zealand Weed and Pest Control Society, Hastings, New Zealand.

Lankin, G., J.E. Araya, y L. Lamborot. 1997. Método de crianza de Diaeretiella rapae (Mcintosh), parasitoide de Brevicoryne brassicae. Bol. Sanid. Veg. Plagas 23:57-61.

Liotta, G. 1978: Effets secondaires des appats protéiques empoisonées sur Opius concolor Szzépl. Hym. Braconidae au laboratoire. Ciencia e Cultura 30(7 Supplement):481-486.

Maniglia, G. 1978. Effets secondaires du carbaryl et de diméthoate sur Opius concolor Szépl. Hym. Braconidae au laboratoire. Ciencia e Cultura 30(7 Supplement):487-491.

Mertins, J.W. 1985. Hyperparasitoids from pea aphid mummies, Acyrthosiphon pisum (Homoptera: Aphididae), in North America. Ann. Entomol. Soc. Am. 78:186-197.
Metcalf, R.L. 1982. Insecticides in pest management. p. 235-273. In Metcalf, R.L., and W.H. Luckman (eds.) Introduction to insect pest management. $2^{\text {nd }} \mathrm{ed}$. Wiley, New York, USA.

Milne, W., and A. Bishop. 1987. The role of predators and parasites in the natural regulation of lucerne aphids in eastern Australia. J. Appl. Ecol. 24:893-905.

Patel, I., B. Prajapati, G. Patel, and A. Pathak. 1996. Relative toxicity of insecticides to Diaeretiella rapae, a hymenopterus parasite of mustard aphid (Lipaphis erysimi). Indian J. Agric. Sci. 66:507-508.

Pike, K.,P.Stary, T. Miller, D. Allison,L. Boydston, G. Graf, and R. Gillespie. 1997. Small-grain aphid parasitoids (Hymenoptera: Aphelinidae and Aphidiidae) of Washington: distribution, relative abundance, seasonal occurrence, and key to known North American species. Environ. Entomol. 26:1299-1311.

Prado, E. 1991. Artrópodos y sus enemigos naturales asociados a plantas cultivadas en Chile. Boletín Técnico INIA $\mathrm{N}^{\circ}$ 169. 207 p. Instituto de Investigaciones Agropecuarias, Santiago, Chile.

Pungerl, N.B. 1984. Host preferences of Aphidius (Hymenoptera: Aphidiidae) populations parasitising pea and cereal aphids (Hemiptera: Aphididae). Bull. Entomol. Res. 74:153-161.

Rodríguez, M. 1980. Manejo y control de plagas en plantas y animales. Vol. 3. 184 p. Limusa, México.

Roos, M., y E. Melo. 1976. Seletividade fisiológica de inseticidas aos predadores de afídios. EMBRAPA Boletim Técnico 3:1-20. Passo Fundo, Brasil.

Sequeira, R., and M. Mackauer. 1993. Seasonal variation in body size and offspring sex ratio in field populations of the parasitoid wasp, Aphidius ervi (Hymenoptera: Aphidiidae). Oikos 68:340-346.

Stark, J., P. Jepson., and D. Mayer. 1995. Limitations to use of topical toxicity data for predictions of pesticide side effects in the field. J. Econ. Entomol. 88:10811088

Stark, J., and T. Rangus. 1994. Lethal and sublethal effects of the neem insecticide formulation, "Margosan-O", on the pea aphid. Pestic. Sci. 41:155-160.

Stary, P. 1966. Aphid parasites of Czechoslovakia. 242 p. W. Junk, The Hague, The Netherlands.

Summers, C., R. Coviello, and W.Z. Cothram. 1975. The effects on selected entomophagous insects of insecticides applied for pea aphid control in alfalfa. Environ. Entomol. 4:612-614.

Syrett, P., and D. Penman. 1980. Studies of insecticide toxicity to lucerne aphids and their predators. N.Z. Agric. Res. 23:575-580.

Theiling, K.M., and B.A. Croft. 1987. Pesticide sideeffects on arthropod natural enemies: A data base summary. Agric. Ecosist. Environ. 2:191-218. 
Thompson, G.D., S.H. Hutchins, and T.C. Sparks. 1999. Development of spinosad and attributes of a new class of insect control products. University of Minnesota, Minneapolis-St. Paul, Minnesota, USA. Available at http://ipmworld.umn.edu/chapters/hutchins2.htm (accessed 18 March 2003).

Zuazúa, F., J.E. Araya, y M.A. Guerrero. 2000. Efecto de varios insecticidas en la longevidad del parasitoide Aphidius ervi Haliday (Hymenoptera: Aphidiidae). Investigación Agrícola (Chile) 20:39-46.
Zuazúa, F., J.E. Araya, y M.A. Guerrero. 2003. Efectos letales de insecticidas sobre Aphidius ervi Haliday (Hymenoptera: Aphidiidae), parasitoide de Acyrtosiphon pisum (Harris) (Homoptera: Aphididae). Bol. Sanid. Veg. Plagas 29:299-307. 